\title{
Cobalt Aluminate Spinel as a Cocatalyst for Photocatalytic Oxidation of Water: Significant Hole-Trapping Effect
}

Tomoki Kanazawa, ${ }^{1,2}$ Kosaku Kato, ${ }^{3}$ Ryusei Yamaguchi, ${ }^{4}$ Tomoki Uchiyama, ${ }^{4}$ Daling Lu, ${ }^{5}$ Shunsuke Nozawa, ${ }^{6}$ Akira Yamakata, ${ }^{* 3}$ Yoshiharu Uchimoto, ${ }^{4}$ and Kazuhiko Maeda ${ }^{* 1}$

${ }^{1}$ Department of Chemistry, School of Science, Tokyo Institute of Technology, 2-12-1-NE-2 Ookayama, Meguro-ku, Tokyo 152-8550, Japan

${ }^{2}$ Japan Society for the Promotion of Science, Kojimachi Business Center Building, 5-3-1 Kojimachi, Chiyoda-ku, Tokyo 102-0083, Japan

${ }^{3}$ Graduate School of Engineering, Toyota Technological Institute, 2-12-1 Hisakata, Tempaku, Nagoya 468-8511, Japan

${ }^{4}$ Graduate school of Human and Environmental Studies, Kyoto University, Yoshida-nihonmatsu-cho, Sakyo-ku, Kyoto 606-8501, Japan

${ }^{5}$ Suzukakedai Materials Analysis Division, Technical Department, Tokyo Institute of Technology, 4259 Nagatsuta-cho, Midori-ku, Yokohama 226-8503, Japan

${ }^{6}$ Institute of Materials Structure Science, High Energy Accelerator Research Organization, 1-1 Oho, Tsukuba, Ibaraki 305-0801, Japan

*To whom correspondence should be addressed.

yamakata@toyota-ti.ac.jp

maedak@chem.titech.ac.jp 


\section{Supporting Information (SI)}

\section{Experimental Section \\ Materials and Reagents}

$\mathrm{Co}\left(\mathrm{NO}_{3}\right)_{2} \cdot 6 \mathrm{H}_{2} \mathrm{O}\left(>98.0 \%\right.$, Wako Pure Chemicals Co.) and $\mathrm{Al}(\mathrm{NO})_{3} \cdot 9 \mathrm{H}_{2} \mathrm{O}(>98 \%$, Sigma Aldrich Co.) were employed as the precursors for the loading of nanoparticulate cobalt-based species.

g- $\mathrm{C}_{3} \mathrm{~N}_{4}$ was prepared by thermal polymerization of cyanamide ( $99 \%$, Sigma Aldrich Co.) according to a previous report. ${ }^{1} 9 \mathrm{~g}$ of cyanamide were heated at $823 \mathrm{~K}$ for $4 \mathrm{~h}$ in air. The Brunauer-Emmett-Teller (BET) surface area was $9 \pm 2 \mathrm{~m}^{2} \mathrm{~g}^{-1}$.

Various semiconductor photocatalysts were prepared by previously reported methods. ${ }^{2-4} \mathrm{TaON}$ was prepared by heating $\mathrm{Ta}_{2} \mathrm{O}_{5}\left(99.9 \%\right.$, Wako Pure Chemicals Co.) at $1113 \mathrm{~K}$ for $15 \mathrm{~h}$ under an $\mathrm{NH}_{3}$ atmosphere (flow rate, $20 \mathrm{~mL} \mathrm{~min}^{-1}$ ). $\mathrm{LaTiO}_{2} \mathrm{~N}$ was prepared by similar thermal ammonolysis of a LaTi oxide precursor, which was synthesized by a polymerized complex method. The oxide precursor was prepared using methanol (150 mL; $>99.8 \%$, Kanto, Chemicals, Co.) containing $0.02 \mathrm{mmol}$ of titanium tetra-isopropoxide (97.0\%, Kanto Chemicals Co.), lanthanum(III) nitrate hexahydrate (99.9\%, Wako Pure Chemicals Co.), ethylene glycol (EG; 99.5\%, Kanto Chemicals Co.), and citric acid (CA; 98.0\%, Wako Pure Chemicals Co.). The molar ratio of $\mathrm{La} / \mathrm{Ti} / \mathrm{EG} / \mathrm{CA}$ was $1 / 1 / 80 / 20$. After stirring at $423 \mathrm{~K}$ overnight, the solution was polymerized through esterification between EG and CA. Then, the polymerized solution was thermally decomposed by heating at $673 \mathrm{~K}$. The carbonized powder was annealed at $823 \mathrm{~K}$ for $2 \mathrm{~h}$ in air, and then at $1273 \mathrm{~K}$ for $10 \mathrm{~h}$. The as-prepared precursor oxide was heated at $1173 \mathrm{~K}$ for $15 \mathrm{~h}$ under $\mathrm{NH}_{3}$ (flow rate, $100 \mathrm{~mL} \mathrm{~min}{ }^{-1}$ ). $\mathrm{TiO}_{2}: \mathrm{Ta}, \mathrm{N}$ was prepared by thermal ammonolysis of $\mathrm{TiO}_{2}$ : Ta, which was synthesized by a hydrothermal method. $20 \mathrm{mmol}$ of titanium tetraisopropoxide and $0.20 \mathrm{mmol}$ of tantalum(V) ethoxide (99.98\%, Sigma Aldrich Co.) were added to $n$ hexane (50 mL; >96.0\%, Kanto Chemicals Co.) containing HCl (5 mL; 35-37\%, Kanto Chemicals Co.). The reaction solution was placed in an autoclave and heated at $423 \mathrm{~K}$ for $2 \mathrm{~h}$ under microwave radiation $(400 \mathrm{~W})$. After washing by $\mathrm{H}_{2} \mathrm{O}$, the precipitate was dried at $353 \mathrm{~K}$ overnight. The as-prepared $\mathrm{TiO}_{2}$ : $\mathrm{Ta}$ was heated at $723 \mathrm{~K}$ for $0.5 \mathrm{~h}$ under $\mathrm{NH}_{3}$ (flow rate, $10 \mathrm{~mL} \mathrm{~min}^{-1}$ ) to obtain $\mathrm{TiO}_{2}$ :Ta, $\mathrm{N}$. The production of $\mathrm{g}-\mathrm{C}_{3} \mathrm{~N}_{4}, \mathrm{TaON}, \mathrm{LaTiO}_{2} \mathrm{~N}$ and $\mathrm{TiO}_{2}$ :Ta, $\mathrm{N}$ was confirmed by X-ray diffraction and $\mathrm{UV}$-visible diffuse reflectance spectroscopy (Figure $\mathrm{S} 1$ ).

\section{Modification of g- $\mathrm{C}_{3} \mathrm{~N}_{4}$ with Nanoparticulate $\mathrm{CoAl}_{2} \mathrm{O}_{4}$}

$\mathrm{CoAl}_{2} \mathrm{O}_{4}$ nanoparticles were loaded onto the $\mathrm{g}-\mathrm{C}_{3} \mathrm{~N}_{4}$ surface using a reverse micelle (RM) method, as shown in Figure $\mathrm{S} 2$. In a typical procedure, $0.02 \mathrm{mmol}$ of $\mathrm{Co}\left(\mathrm{NO}_{3}\right)_{2} \cdot 6 \mathrm{H}_{2} \mathrm{O}$ and $0.04 \mathrm{mmol}$ of $\mathrm{Al}\left(\mathrm{NO}_{3}\right)_{3} \cdot 9 \mathrm{H}_{2} \mathrm{O}$ were dissolved in pure water $(2 \mathrm{~mL})$. Polyoxyethylene $(5)$ nonylphenyl ether $(4.2 \mathrm{~mL}$; IGEPAL®CO-520, Sigma Aldrich Co.) as surfactant and cyclohexane $(5.5 \mathrm{~mL} ;>99.5 \%$, Kanto Chemicals Co.) as solvent were added into the aqueous solution, in which the surfactant/water molar ratio was 6 . Another solution, $0.2 \mathrm{mmol}$ of tetramethylammonium hydroxide pentahydrate (TMAH, $>97.0 \%$, Tokyo Chemical Industry Co., Ltd.) was dissolved in $\mathrm{H}_{2} \mathrm{O}(1 \mathrm{~mL})$, followed by addition of polyoxyethylene $(5)$ nonylphenyl ether $(4.2 \mathrm{~mL})$ and cyclohexane $(5.5 \mathrm{~mL})$. After separately stirring these solutions for $1 \mathrm{~h}$, they were mixed together with continuous stirring overnight and ethanol $(20 \mathrm{~mL}$ $>99.5 \%$, Kanto Chemicals Co.) was added to the solution. Then, $150 \mathrm{mg}$ of $\mathrm{g}-\mathrm{C}_{3} \mathrm{~N}_{4}$ was added, followed by stirring for $0.5 \mathrm{~h}$ and then filtration of the suspension. Analysis of the filtrate by inductively coupled plasma optical emission spectrometry (ICP-OES; $5100 \mathrm{VDV}$, Agilent Technologies) indicated that neither Co nor Al was present in the solution. The residual solids were washed with cyclohexane 3 times to remove the excess surfactant. All of these procedures were performed at room temperature. After redispersing the resulting solid into ethanol, the suspension was evaporated at $373 \mathrm{~K}$ to dryness. Then, the powder was heated at $673 \mathrm{~K}$ for $1 \mathrm{~h}$ in air. Thermogravimetric analysis (TG, DTG-60, Shimadzu) indicated that the total loading of $\mathrm{Co}$ and $\mathrm{Al}$ species on the $\mathrm{g}-\mathrm{C}_{3} \mathrm{~N}_{4}$ was very close to the nominal loading amount (Figure S3). In this paper, the Co-Al loading amount was, therefore, reported as the $\mathrm{CoAl}_{2} \mathrm{O}_{4}$ content. Nanoparticulate $\mathrm{Co}_{3} \mathrm{O}_{4}$ was loaded in a similar manner but without $\mathrm{Al}\left(\mathrm{NO}_{3}\right)_{3} \cdot 9 \mathrm{H}_{2} \mathrm{O}$. 


\section{Supporting Information (SI)}

$\mathrm{Co}(\mathrm{OH})_{2}$ was loaded by a method reported previously. ${ }^{5} \mathrm{~g}-\mathrm{C}_{3} \mathrm{~N}_{4}$ was suspended in an aqueous solution of $\mathrm{Co}\left(\mathrm{NO}_{3}\right)_{2} \cdot 6 \mathrm{H}_{2} \mathrm{O}$. After adding $\mathrm{NH}_{3}$ solution (35 wt $\%$, Wako Pure Chemicals Co.), the solution was evaporated to dryness at $373 \mathrm{~K}$. Then, the powder was dried in an oven at $353 \mathrm{~K}$ for $12 \mathrm{~h}$.

$\mathrm{RuO}_{2}$ was loaded by a previously reported method. ${ }^{1} 0.015 \mathrm{mmol}$ of $\left[\mathrm{Ru}_{3}(\mathrm{CO})_{12}\right](99 \%$, Aldrich Chemical Co.) was dissolved in tetrahydrofuran $(20 \mathrm{~mL} ; 99.5 \%$, Kanto Chemicals Co.). After dispersion of $150 \mathrm{mg}$ of $\mathrm{g}-\mathrm{C}_{3} \mathrm{~N}_{4}$, the solution was stirred at $333 \mathrm{~K}$ for $4 \mathrm{~h}$. After drying under reduced pressure, the resulting powder was annealed at $573 \mathrm{~K}$ for $1 \mathrm{~h}$ under air.

\section{Characterization}

The synthesized samples were characterized by X-ray diffraction (XRD; Rigaku MiniFlex600; $\mathrm{Cu}$ $\mathrm{K} \alpha$ ), X-ray photoelectron spectroscopy (XPS; Shimadzu, ESCA-3400; Mg anode), high-resolution transmission electron microscopy (HR-TEM; JEOL, JEM 2010F) and UV-visible diffuse reflectance spectroscopy (DRS; JASCO, V-565). The binding energies determined by XPS were calibrated with respect to the $\mathrm{C} 1 \mathrm{~s}$ peak $(285.0 \mathrm{eV})$ for each sample. The BET surface areas were determined at $77 \mathrm{~K}$ using a BELSORP-mini instrument (MicrotracBEL).

Co K-edge XAFS measurements were conducted on the BL01B1 beamline of the SPring-8 (Proposal No. 2019A1018, 2019A1020, 2019B1899) and the BL-9C beamline of the Photon Factory (Proposal No. 2018G667). XAFS spectra were acquired in the transmission and fluorescence modes at room temperature using a Si(111) double-crystal-monochromator. A Lytle detector was used for measurement in the fluorescence mode. A pair of Rh-coated mirrors was used to eliminate higher harmonics. The XANES spectra were analyzed using the Athena software package. ${ }^{6}$

\section{Photocatalytic Water Oxidation}

Photocatalytic water oxidation reactions were conducted at room temperature in a Pyrex topped irradiation-type reaction vessel connected to a glass-enclosed gas circulation system. The reactant solution was an aqueous solution $(140 \mathrm{~mL})$ of $50 \mathrm{mg}$ of $\mathrm{CoAl}_{2} \mathrm{O}_{4} / \mathrm{g}-\mathrm{C}_{3} \mathrm{~N}_{4}, 10 \mathrm{mM} \mathrm{AgNO} 3(>99.8 \%$, Wako Pure Chemicals Co.) and $200 \mathrm{mg}$ of $\mathrm{La}_{2} \mathrm{O}_{3}(>99.9 \%$, Tokyo Chemical Industry Co., Ltd.). The purchased $\mathrm{La}_{2} \mathrm{O}_{3}$ was heated in air at $1273 \mathrm{~K}$ for $1 \mathrm{~h}$ prior to use to eliminate impurity phases (e.g., hydroxide and carbonate). $\mathrm{La}_{2} \mathrm{O}_{3}$ used in the water oxidation reaction acted as a buffer to adjust the solution $\mathrm{pH}$ to 8.0-8.5. ${ }^{1-2}$ After degassing the solution cell under vacuum, a small amount of argon (3.6 $\mathrm{kPa}$ ) gas was introduced. The reaction cell was irradiated by a $300 \mathrm{~W}$ xenon lamp (Cermax, PE300BF) fitted with a CM1 mirror, the beam passing through a water filter; the output current was $20 \mathrm{~A}$. The wavelength of the incident light was controlled with a L-42 cutoff filter. The evolved gases were analyzed by on-line gas chromatography (GL Science GC-3200 with a thermal conductivity detector and an MS5A column with argon as carrier gas).

The apparent quantum yield (AQY) was calculated using the following equation:

$$
\mathrm{AQY}(\%)=(A \times R / I) \times 100
$$

where $A, R$, and $I$ represent coefficients (for the $\mathrm{O}_{2}$ evolution reaction, $A=4$ ), the $\mathrm{O}_{2}$ evolution rate and the rate of incident photons, respectively. The total number of incident photons $(11.3 \mathrm{~mW})$ from a 300 W xenon lamp (Asahi Spectra, MAX-303) was measured using a power meter. The irradiation wavelength was controlled by a band-pass filter and the water filter $(\lambda=420 \mathrm{~nm})$.

\section{Transient Absorption Spectroscopy}

Measurements were conducted using a purpose-built spectrometer described previously. ${ }^{7} \mathrm{~g}-\mathrm{C}_{3} \mathrm{~N}_{4}$ and $\mathrm{CoAl}_{2} \mathrm{O}_{4} / \mathrm{g}-\mathrm{C}_{3} \mathrm{~N}_{4}$ were deposited on a $\mathrm{CaF}_{2}$ plate at a density of $0.75 \mathrm{mg} \mathrm{cm}^{-2}$ and placed into an IR cell for measurement. Prior to measurements, the sample was heated at $473 \mathrm{~K}$ to remove surface adsorbed species such as water. The samples were photoexcited using $420 \mathrm{~nm}$ pulses from an Nd:YAG laser (Continuum Surelite; duration, $6 \mathrm{~ns}$; power, $5 \mathrm{~mJ}$; repetition rate, $0.1-5 \mathrm{~Hz}$ ), and the transient absorptions in the visible to mid-IR region were measured under $\mathrm{N}_{2}(20$ Torr). The time resolution of the spectrometer was limited to 1-2 $\mu$ s as dictated by the bandwidth of the amplifier (Stanford Research Systems, SR560, $1 \mathrm{MHz})$. 
(A) XRD
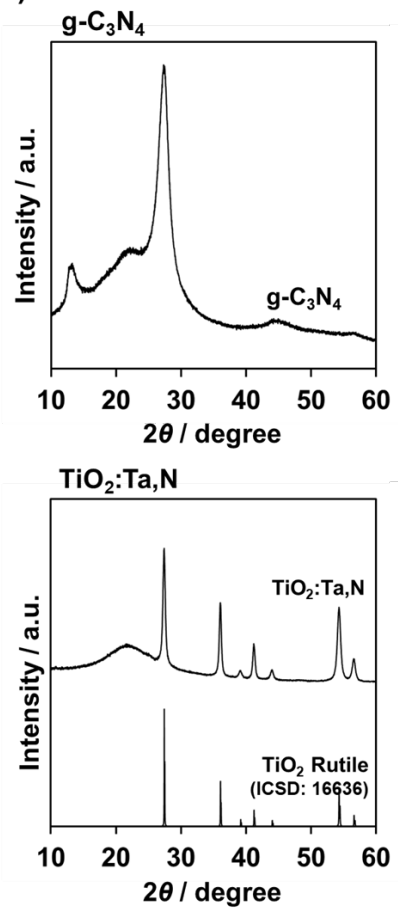
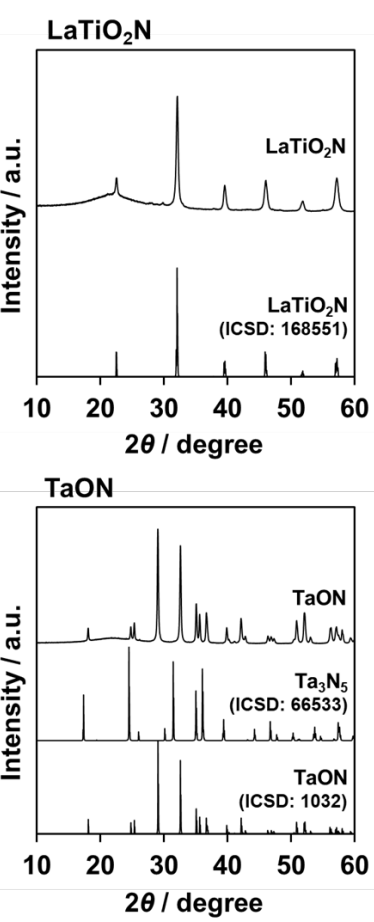

(B) DRS
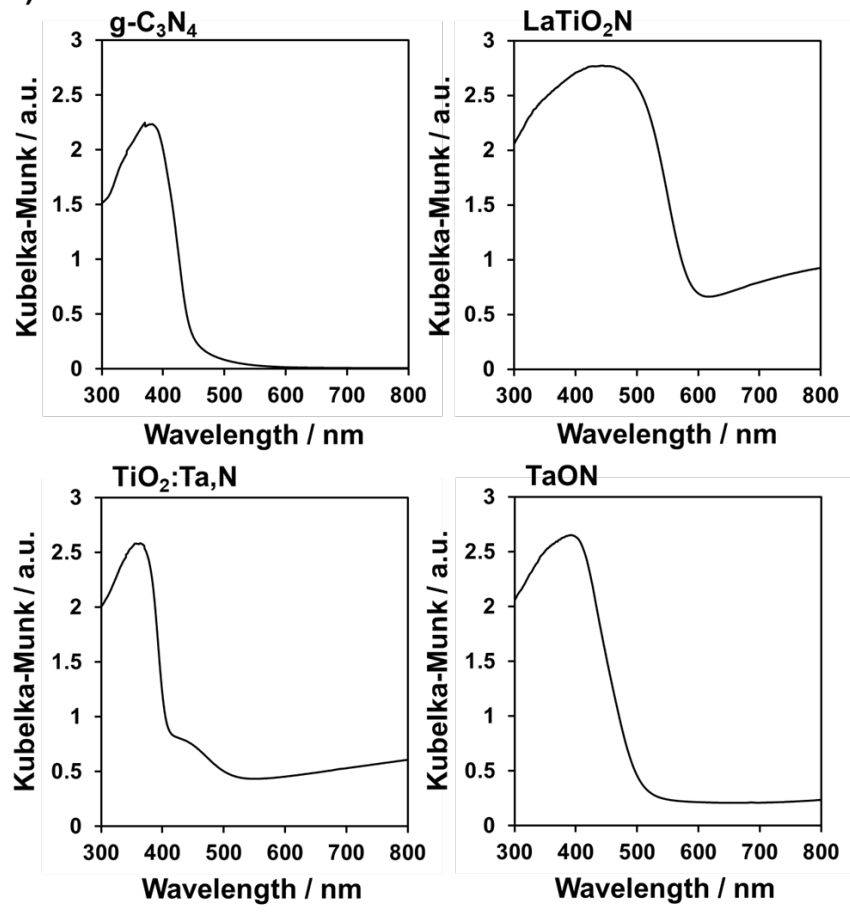

Figure S1. (A) XRD patterns and (B) UV-visible diffuse reflectance spectra of the various semiconductor photocatalysts used in this work.

$$
\begin{aligned}
& 1 \mathrm{~mL} \mathrm{H}_{2} \mathrm{O} \\
& \downarrow \begin{array}{ll}
0.02 \mathrm{mmol} & \mathrm{Co}\left(\mathrm{NO}_{3}\right)_{2} \cdot 6 \mathrm{H}_{2} \mathrm{O} \\
0.04 \mathrm{mmol} & \mathrm{Al}\left(\mathrm{NO}_{3}\right)_{3} \cdot 9 \mathrm{H}_{2} \mathrm{O}
\end{array} \\
& \text { Co-Al nitrate aq. } \\
& \longleftarrow 4.2 \mathrm{~mL} \text { IGEPAL } \circledast \mathrm{CO}-520 \\
& \longleftarrow 5.5 \mathrm{~mL} \text { Cyclohexane } \\
& \text { Stirring for } 1 \mathrm{~h} \\
& \text { Co-Al reverse micelle solution }
\end{aligned}
$$

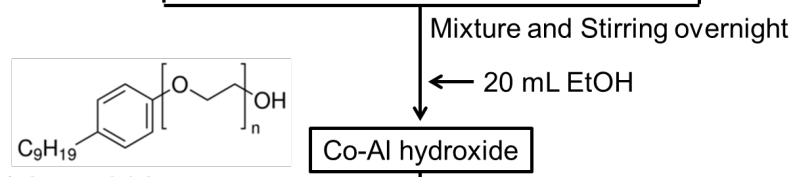

$$
\begin{aligned}
& \text { *IGEPAL } \circledast \text { CO-520 } \\
& \text { as surfactant } \\
& 1 \mathrm{~mL} \mathrm{H}_{2} \mathrm{O} \\
& 0.2 \mathrm{mmol} \text { TMAH } \\
& \leftarrow \text { (Tetramethylammonium } \\
& \text { hydroxide pentahydrate) } \\
& \text { TMAH aq. } \\
& \longleftarrow 4.2 \mathrm{~mL} \text { IGEPAL } \circledast \mathrm{CO}-520 \\
& \leftarrow 5.5 \mathrm{~mL} \text { Cyclohexane } \\
& \text { Stirring for } 1 \mathrm{~h}
\end{aligned}
$$

\begin{tabular}{l|l} 
& $\longleftarrow 150 \mathrm{mg} \mathrm{g}-\mathrm{C}_{3} \mathrm{~N}_{4}$, stirring for $0.5 \mathrm{~h}$ \\
& $\begin{array}{l}\longleftarrow \\
\text { Filtration and washing by cyclohexane } \\
\text { Dispersion into } \mathrm{EtOH} \\
\text { Drying at } 373 \mathrm{~K} \\
\text { Annealed at } 473-723 \mathrm{~K} \text { under Air }\end{array}$ \\
$\mathrm{CoAl}_{2} \mathrm{O}_{4} / \mathrm{g}^{-} \mathrm{C}_{3} \mathrm{~N}_{4}$
\end{tabular}

Figure S2. Overview of preparation stages for $\mathrm{CoAl}_{2} \mathrm{O}_{4}$ loading onto $\mathrm{g}-\mathrm{C}_{3} \mathrm{~N}_{4}$ by the reverse micelle method. 


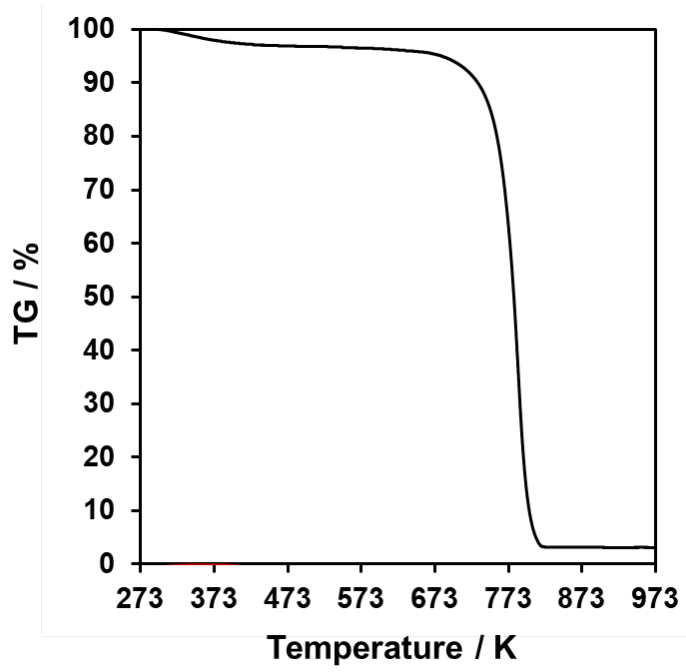

Figure S3. TG curve of $3.0 \mathrm{wt} \% \mathrm{CoAl}_{2} \mathrm{O}_{4}$-loaded $\mathrm{g}-\mathrm{C}_{3} \mathrm{~N}_{4}$ under air (flow rate, $100 \mathrm{~mL} \mathrm{~min}^{-1}$ ) with a ramp rate of $1 \mathrm{~K} \mathrm{~min}^{-1}$. The initial weight loss observed up to $473 \mathrm{~K}$ is attributed to adsorbed water molecules. The component that remained at $973 \mathrm{~K}$ should be $\mathrm{CoAl}_{2} \mathrm{O}_{4}$, because $\mathrm{g}-\mathrm{C}_{3} \mathrm{~N}_{4}$ decomposed completely upon heating in air at that temperature. The calculated amount of $\mathrm{CoAl}_{2} \mathrm{O}_{4} \mathrm{was} 3.2 \mathrm{wt} \%$, very close to the nominal loading amount.

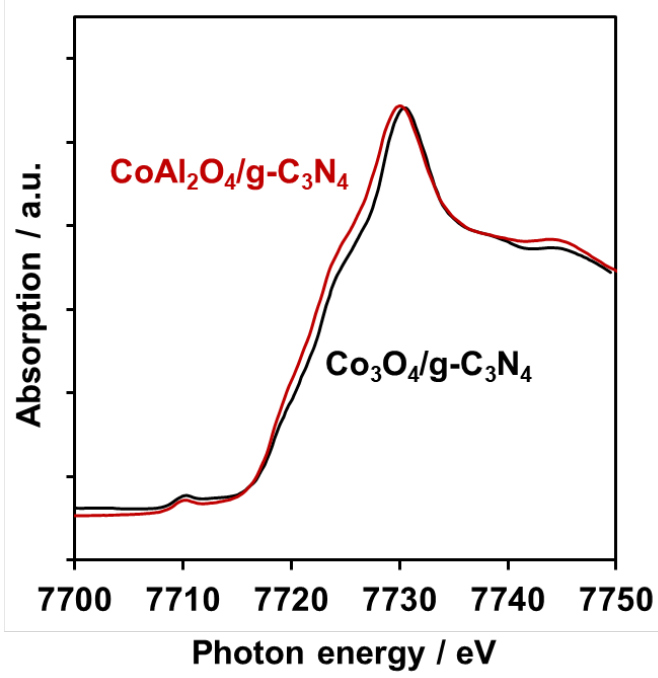

Figure S4. Co K-edge XANES spectra for $3.0 \mathrm{wt} \% \mathrm{CoAl}_{2} \mathrm{O}_{4} / \mathrm{g}-\mathrm{C}_{3} \mathrm{~N}_{4}$ and $1.5 \mathrm{wt} \% \mathrm{Co}_{3} \mathrm{O}_{4} / \mathrm{g}-\mathrm{C}_{3} \mathrm{~N}_{4}$. 

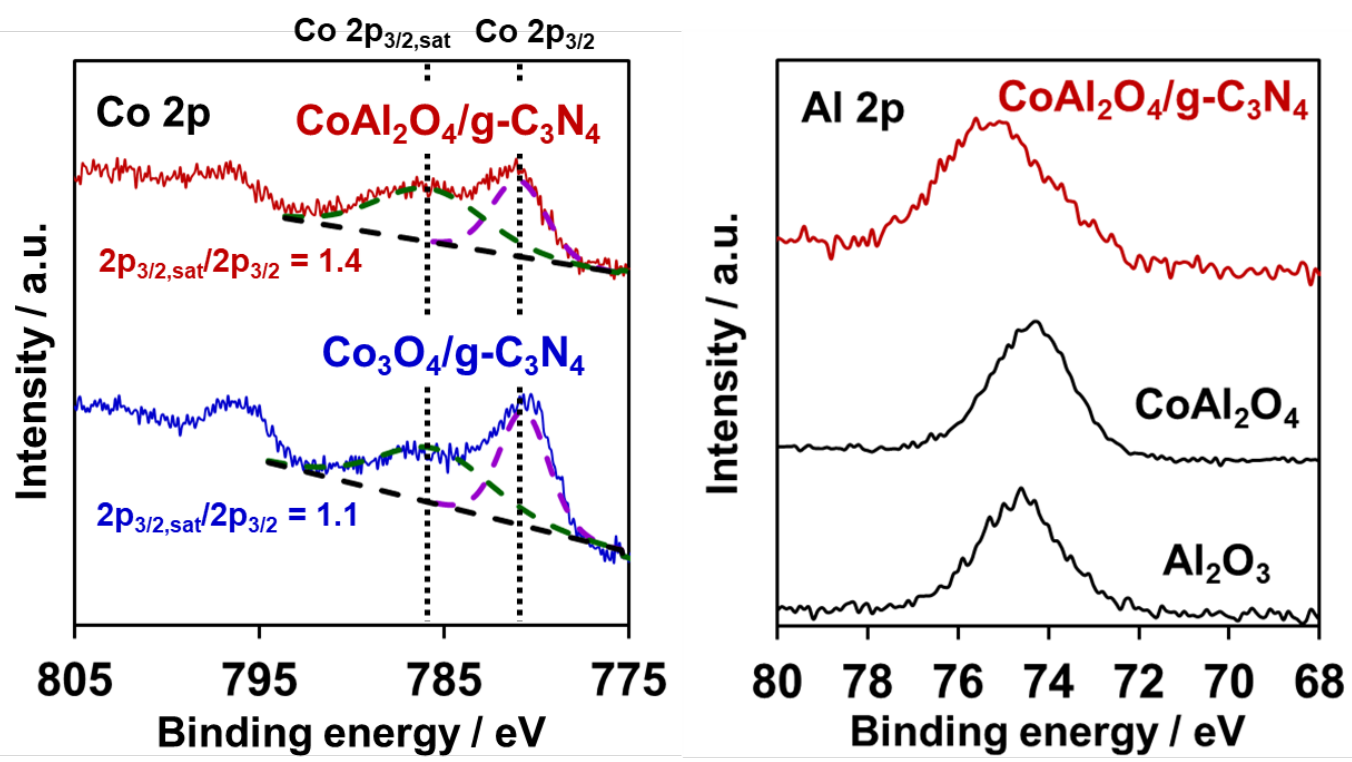

Figure S5. Co $2 p$ and $\mathrm{Al} 2 \mathrm{p}$ XPS spectra for $\mathrm{CoAl}_{2} \mathrm{O}_{4} / g-\mathrm{C}_{3} \mathrm{~N}_{4}$ and $\mathrm{Co}_{3} \mathrm{O}_{4} / g-\mathrm{C}_{3} \mathrm{~N}_{4}$. Spectra for $\mathrm{CoAl}_{2} \mathrm{O}_{4}$ and $\mathrm{Al}_{2} \mathrm{O}_{3}$ are shown for reference purposes. Although the $\mathrm{Co} 2 \mathrm{p}_{3 / 2}$ peak contained contributions of both $\mathrm{Co}^{2+}$ and $\mathrm{Co}^{3+}$, the presence of a $\mathrm{Co}^{2+}$ satellite peak at $786.3 \mathrm{eV}$ could be a measure of evaluating the population of $\mathrm{Co}^{2+}$ in $\mathrm{CoAl}_{2} \mathrm{O}_{4} / g-\mathrm{C}_{3} \mathrm{~N}_{4}$ and $\mathrm{Co}_{3} \mathrm{O}_{4} / g-\mathrm{C}_{3} \mathrm{~N}_{4}$. It is clear that the ratio of the $\mathrm{Co}^{2+}$ satellite to the main $\mathrm{Co} 2 \mathrm{p}_{3 / 2}$ was higher in $\mathrm{CoAl}_{2} \mathrm{O}_{4} / g-\mathrm{C}_{3} \mathrm{~N}_{4}$ than in $\mathrm{Co}_{3} \mathrm{O}_{4} / g-\mathrm{C}_{3} \mathrm{~N}_{4}$.
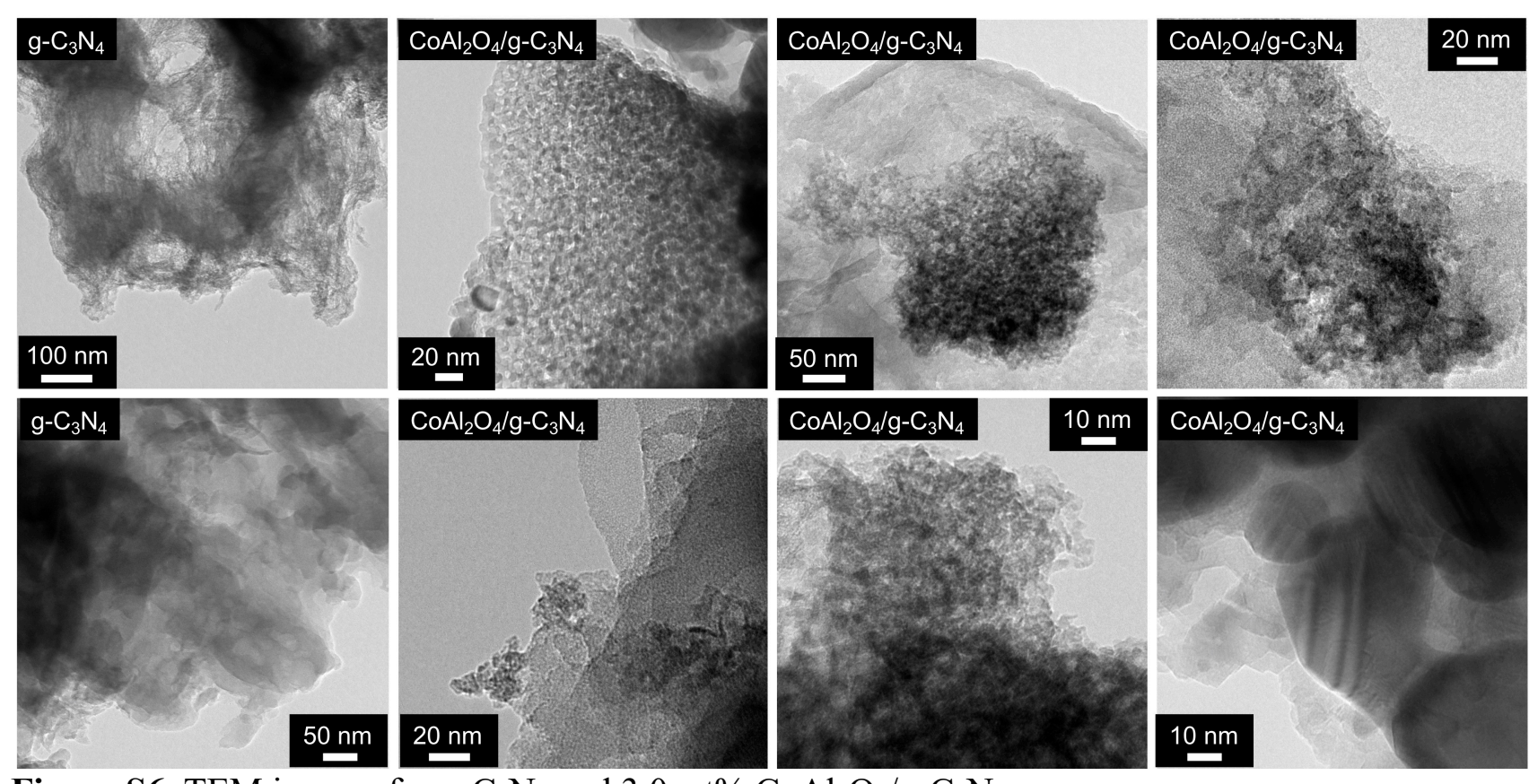

Figure S6. TEM images for $\mathrm{g}-\mathrm{C}_{3} \mathrm{~N}_{4}$ and $3.0 \mathrm{wt} \% \mathrm{CoAl}_{2} \mathrm{O}_{4} / \mathrm{g}-\mathrm{C}_{3} \mathrm{~N}_{4}$. 


\section{Supporting Information (SI)}
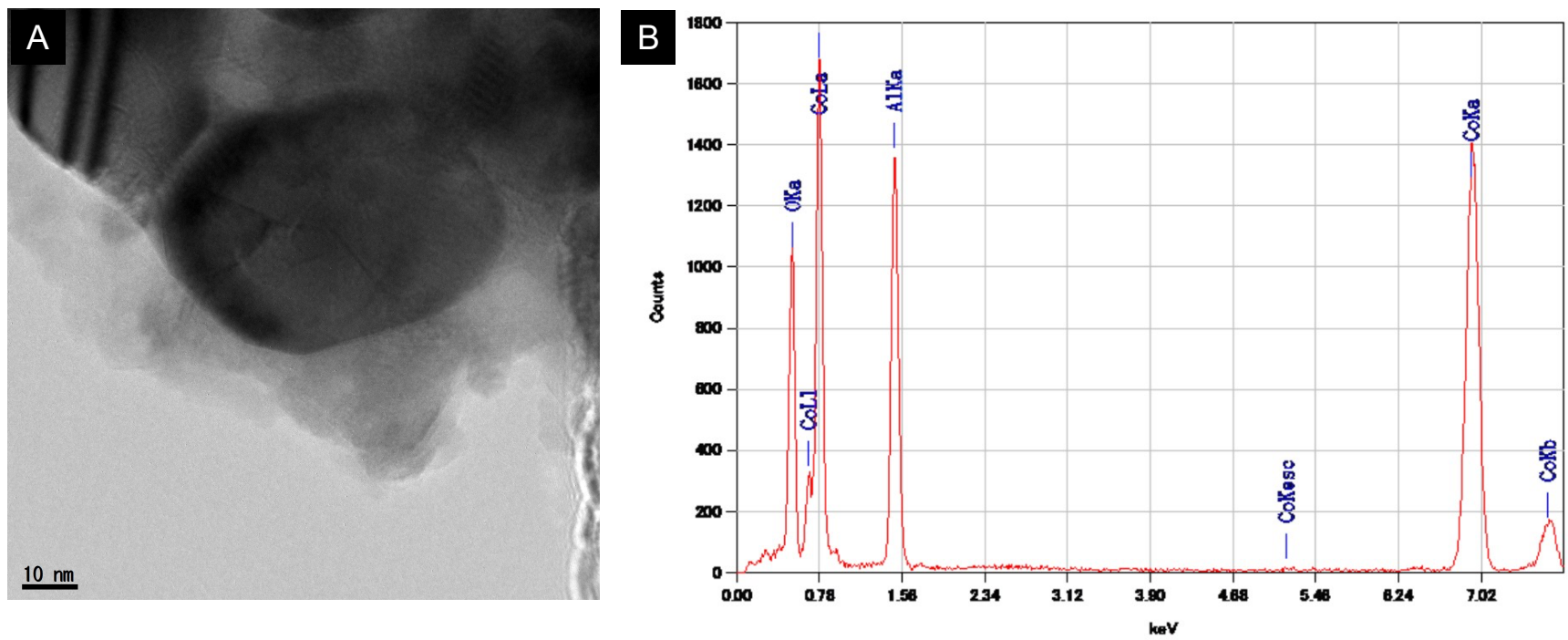

Figure S7. Result of TEM/EDS analysis for $3.0 \mathrm{wt} \% \mathrm{CoAl}_{2} \mathrm{O}_{4} / \mathrm{g}-\mathrm{C}_{3} \mathrm{~N}_{4}$. The spot area for EDS was approximately $5 \mathrm{~nm}$.
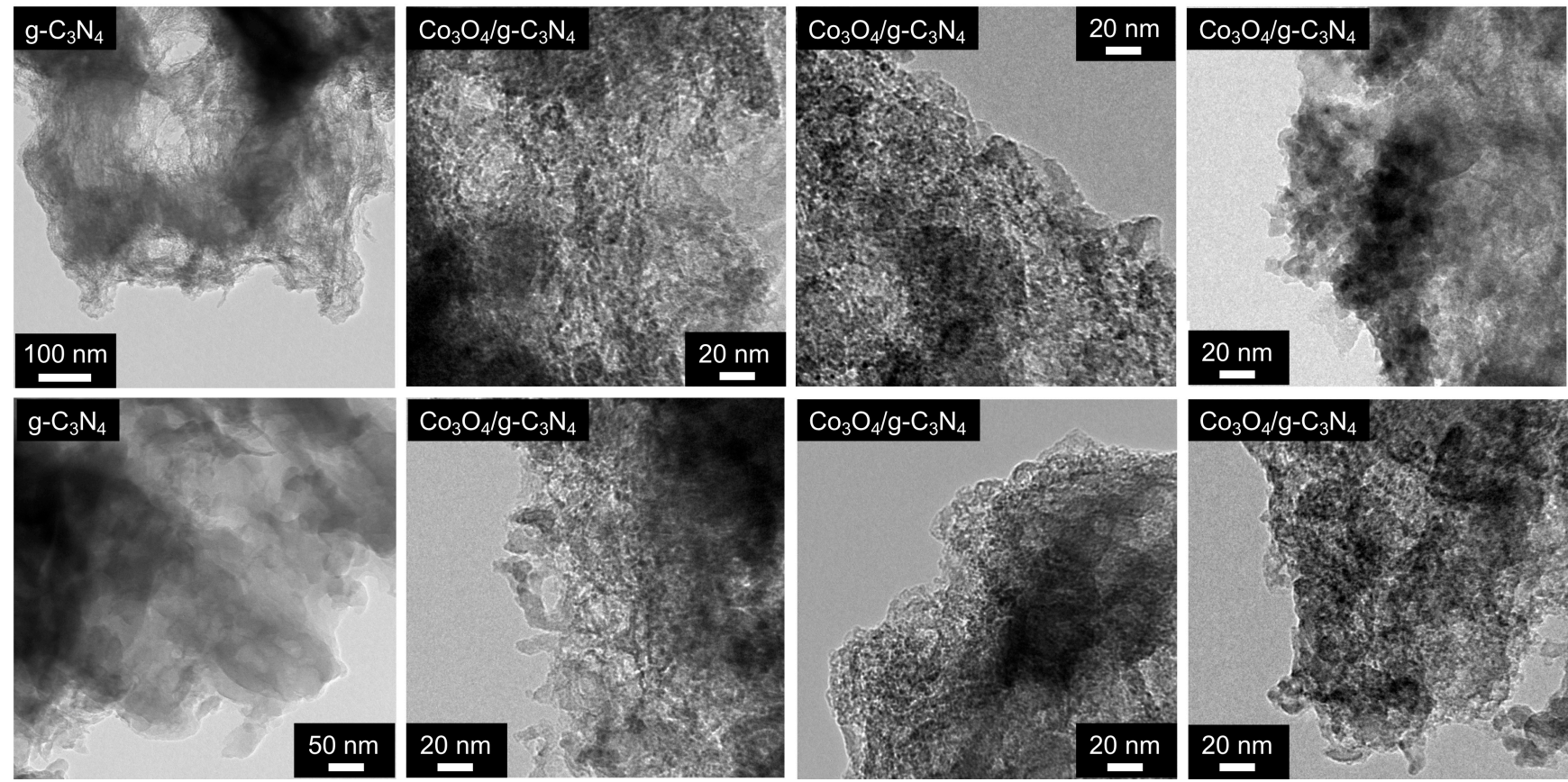

Figure S8. TEM images for $\mathrm{g}-\mathrm{C}_{3} \mathrm{~N}_{4}$ and $1.5 \mathrm{wt} \% \mathrm{Co}_{3} \mathrm{O}_{4} / \mathrm{g}-\mathrm{C}_{3} \mathrm{~N}_{4}$. 
(1) None

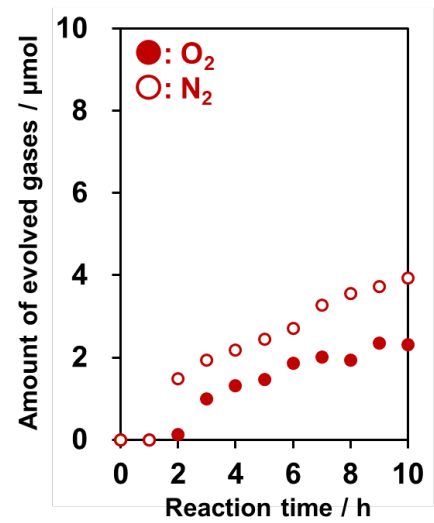

(5) $\mathrm{Co}(\mathrm{OH})_{2}, 3.0 \mathrm{wt} \%$

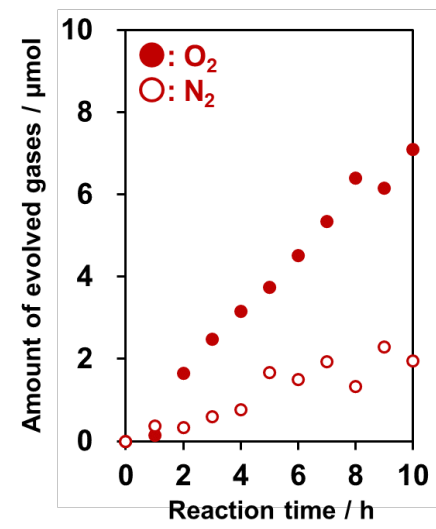

(2) $\mathrm{CoAl}_{2} \mathrm{O}_{4}, 3.0$ wt\%

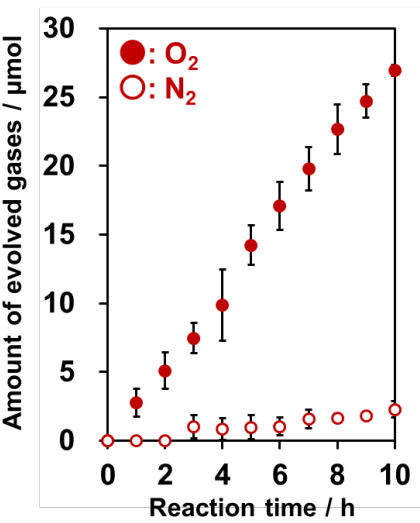

(6) $\mathrm{RuO}_{2}, 3.0 \mathrm{wt} \%$

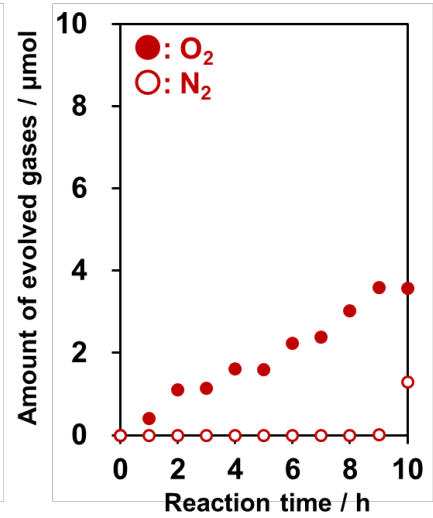

(3) $\mathrm{Co}_{3} \mathrm{O}_{4}, 1.5 \mathrm{wt} \%$

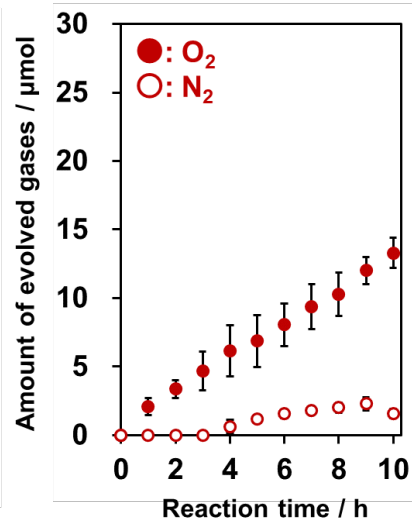

(7) $\mathrm{IrO}_{x}, 3.0 \mathrm{wt} \%$

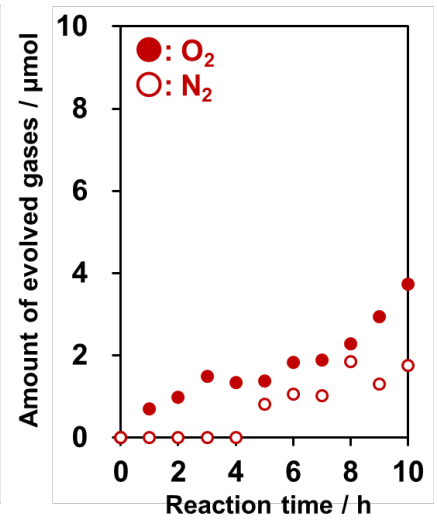

(4) $\mathrm{Al}_{2} \mathrm{O}_{3}, 1.5 \mathrm{wt} \%$

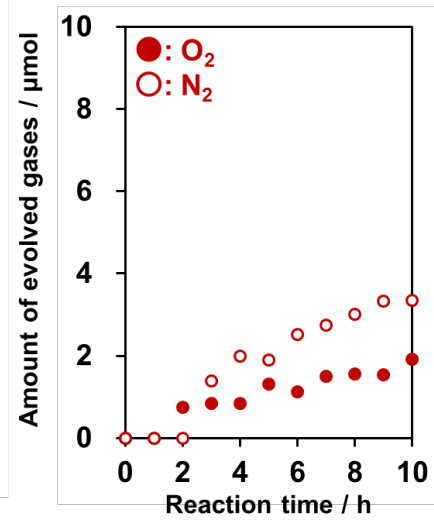

Figure S9. Time course of photocatalytic $\mathrm{O}_{2}$ evolution over $\mathrm{g}-\mathrm{C}_{3} \mathrm{~N}_{4}$ modified with various cocatalysts. Reaction conditions: catalyst, $50 \mathrm{mg}$; $\mathrm{La}_{2} \mathrm{O}_{3}, 200 \mathrm{mg}$; reactant solution, aqueous $\mathrm{AgNO}_{3}(10 \mathrm{mM}, 140$ $\mathrm{mL}$ ); light source, $300 \mathrm{~W}$ xenon lamp with cutoff filter (L42).
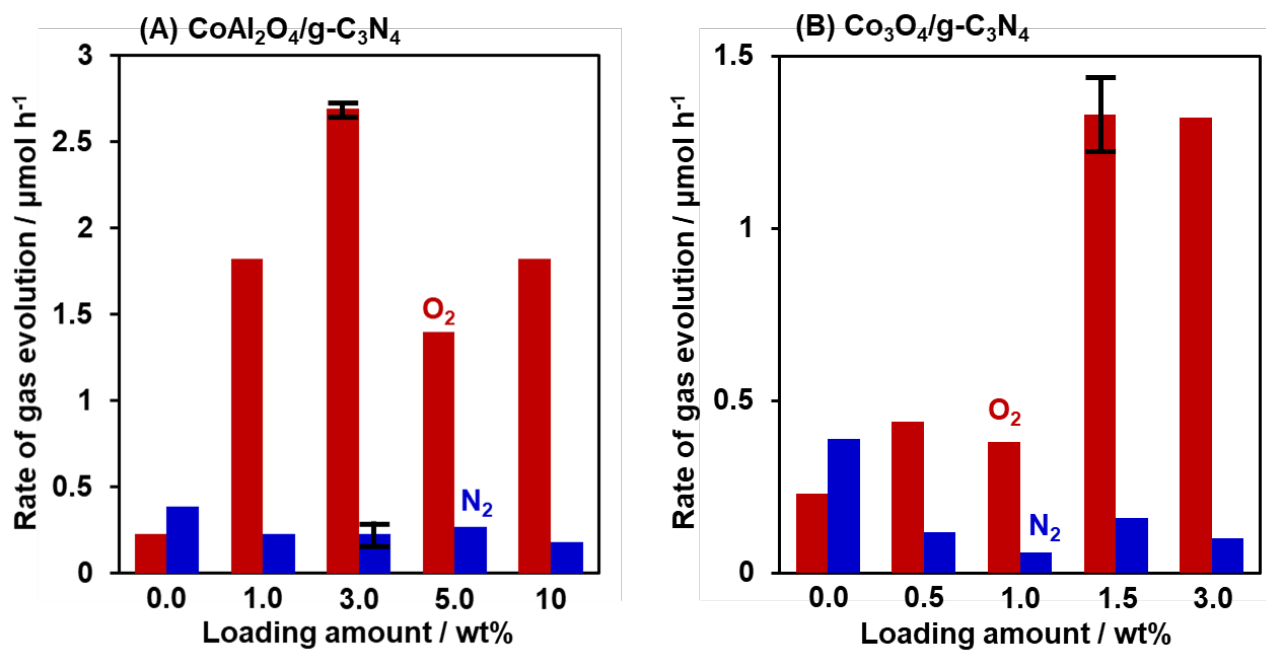

Figure S10. Variations in the photocatalytic $\mathrm{O}_{2}$ evolution rates over (A) $\mathrm{CoAl}_{2} \mathrm{O}_{4} / \mathrm{g}-\mathrm{C}_{3} \mathrm{~N}_{4}$ and (B) $\mathrm{Co}_{3} \mathrm{O}_{4} / \mathrm{g}-\mathrm{C}_{3} \mathrm{~N}_{4}$ with different loading amounts. Reaction conditions: catalyst, $50 \mathrm{mg} ; \mathrm{La}_{2} \mathrm{O}_{3}, 200 \mathrm{mg}$; reactant solution, aqueous $\mathrm{AgNO}_{3}(10 \mathrm{mM}, 140 \mathrm{~mL})$; light source, $300 \mathrm{~W}$ xenon lamp with cutoff filter (L42). Gas evolution rates shown are based on the average values for $10 \mathrm{~h}$ of reaction. 

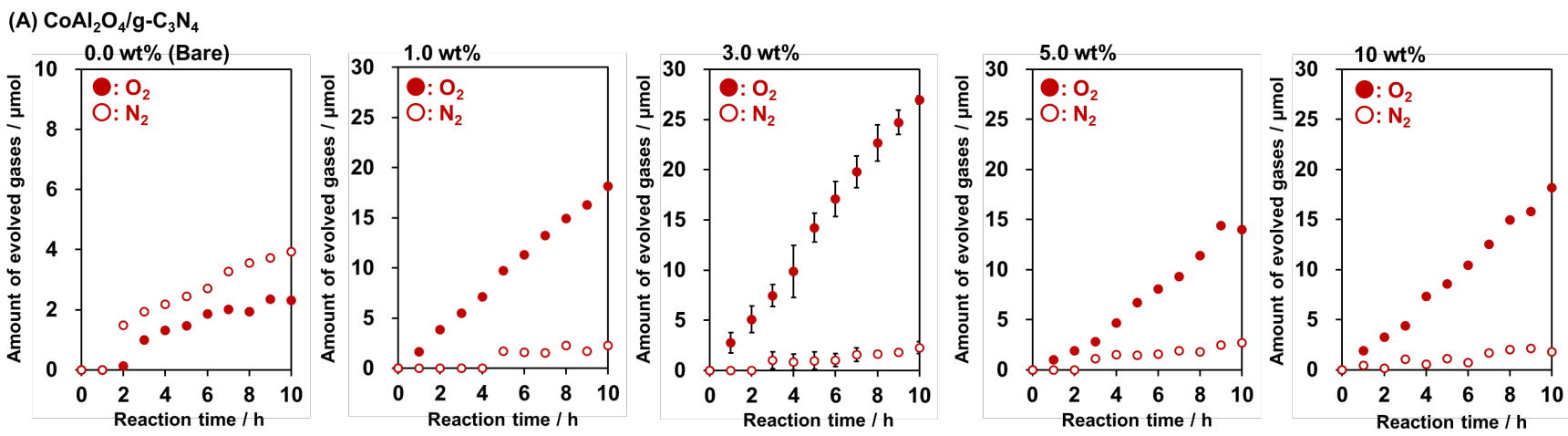

(B) $\mathrm{Co}_{3} \mathrm{O}_{4} / \mathrm{g}-\mathrm{C}_{3} \mathrm{~N}_{4}$
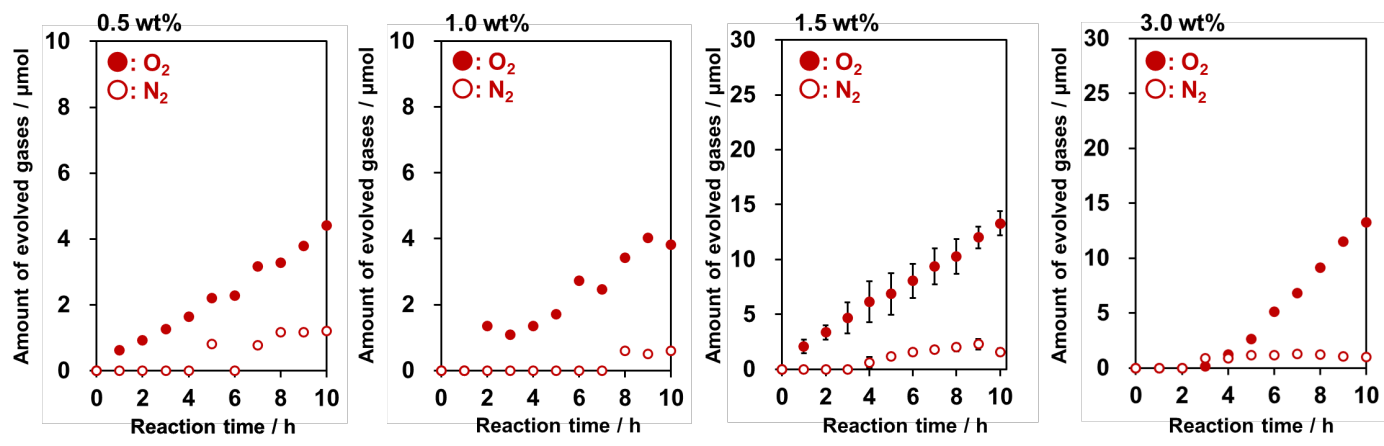

Figure S11. Time course of photocatalytic $\mathrm{O}_{2}$ evolution over (A) $\mathrm{CoAl}_{2} \mathrm{O}_{4} / \mathrm{g}-\mathrm{C}_{3} \mathrm{~N}_{4}$ and (B) $\mathrm{Co}_{3} \mathrm{O}_{4} / g-$ $\mathrm{C}_{3} \mathrm{~N}_{4}$ with different loading amounts. Reaction conditions were the same as shown in Figure S10.
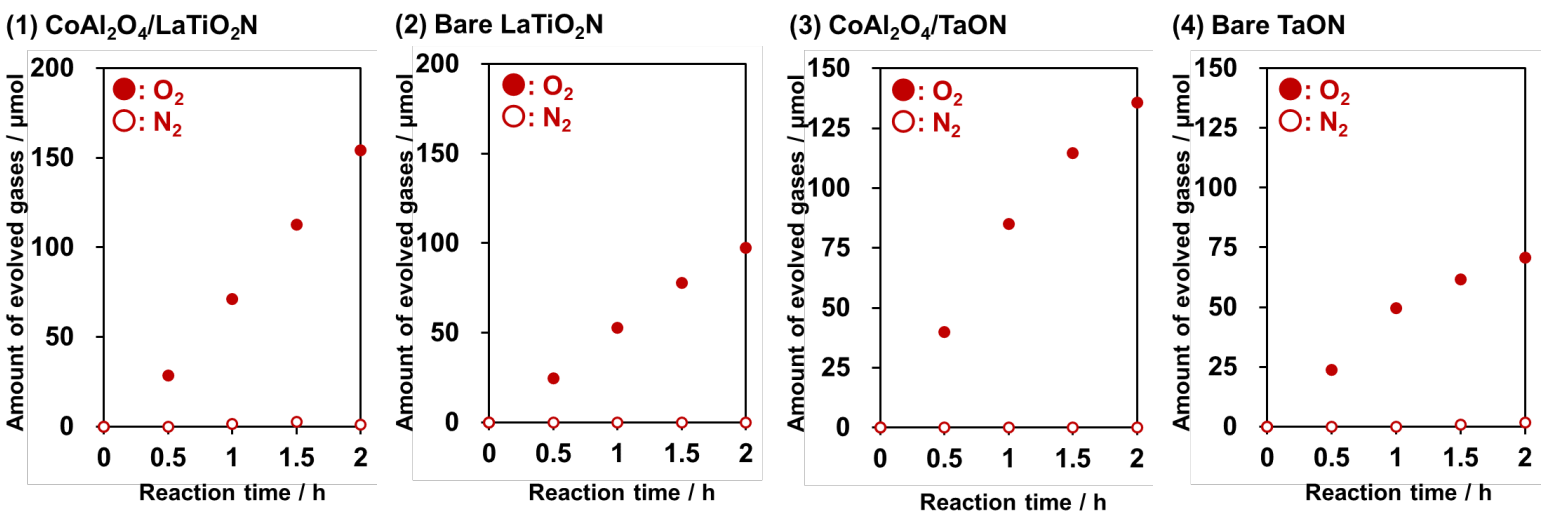

(5) $\mathrm{CoAl}_{2} \mathrm{O}_{4} / \mathrm{TiO}_{2}: \mathrm{Ta}, \mathrm{N}$
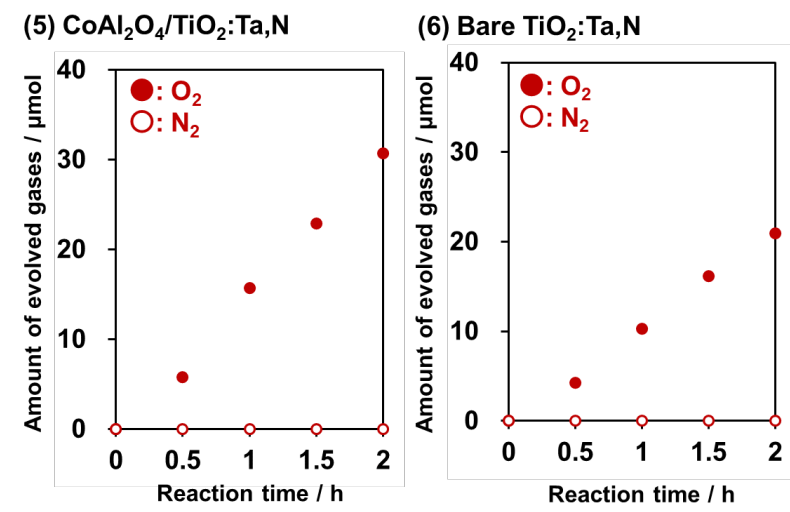

Figure S12. Time course of photocatalytic $\mathrm{O}_{2}$ evolution over various semiconductors modified with $\mathrm{CoAl}_{2} \mathrm{O}_{4}$. Reaction conditions were the same as shown in Table $\mathrm{S} 1$. 


\section{Supporting Information (SI)}
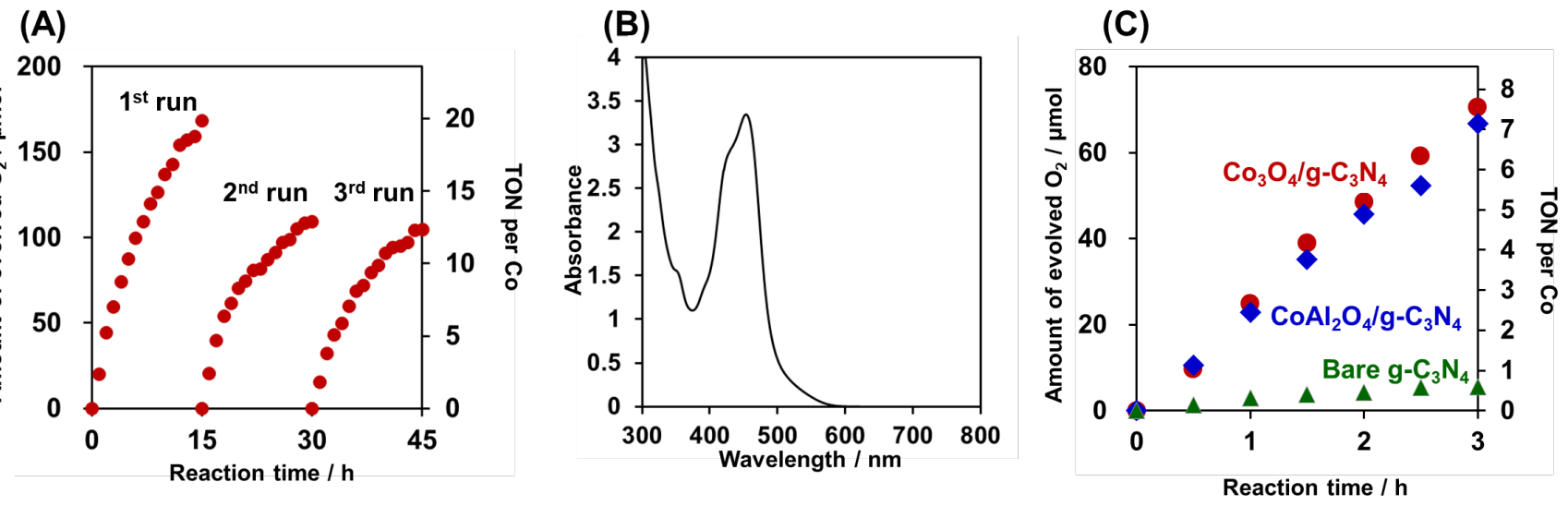

Figure S13. (A) Time course of $\mathrm{O}_{2}$ evolution over $3.0 \mathrm{wt} \% \mathrm{CoAl}_{2} \mathrm{O}_{4} / \mathrm{g}-\mathrm{C}_{3} \mathrm{~N}_{4}$ in three repetitive examinations under visible light irradiation $(\lambda>520 \mathrm{~nm})$ in aqueous phosphate buffer solution $(50 \mathrm{mM}$, $\mathrm{pH} 7.5,100 \mathrm{~mL})$ containing $\mathrm{Na}_{2} \mathrm{~S}_{2} \mathrm{O}_{8}(5 \mathrm{mM})$ and $\left[\mathrm{Ru}(\text { bpy })_{3}\right] \mathrm{SO}_{4}(0.25 \mathrm{mM})$. The reaction system was refreshed at $15 \mathrm{~h}$ intervals by replacing the reactant solution. The $\mathrm{CoAl}_{2} \mathrm{O}_{4} / \mathrm{g}-\mathrm{C}_{3} \mathrm{~N}_{4}$ catalyst was reused for each run. Under present conditions, the main light absorber was $\left[\mathrm{Ru}(\mathrm{bpy})_{3}\right]^{2+}$ (see panel $\mathrm{B}$ for the absorption spectrum of the $0.25 \mathrm{mM}\left[\mathrm{Ru}(\mathrm{bpy})_{3}\right] \mathrm{SO}_{4}$ solution), not $\mathrm{g}_{-} \mathrm{C}_{3} \mathrm{~N}_{4}$. Therefore, the observed $\mathrm{O}_{2}$ evolution originated mostly from the catalytic effect of $\mathrm{CoAl}_{2} \mathrm{O}_{4}$ for water oxidation. The turnover number $(\mathrm{TON})$ of $\mathrm{O}_{2}$ evolution per Co species is also shown in panel A. The panel (C) shows comparison of activities of $\mathrm{g}-\mathrm{C}_{3} \mathrm{~N}_{4}, 3.0 \mathrm{wt} \% \mathrm{CoAl}_{2} \mathrm{O}_{4} / \mathrm{g}-\mathrm{C}_{3} \mathrm{~N}_{4}$ and $1.5 \mathrm{wt} \% \mathrm{Co}_{3} \mathrm{O}_{4} / \mathrm{g}-\mathrm{C}_{3} \mathrm{~N}_{4}$

\section{Experimental Details of the Photochemical Water Oxidation ${ }^{8}$}

$\left[\mathrm{Ru}(\mathrm{bpy})_{3}\right] \mathrm{SO}_{4}$ (bpy $=2,2$ '-bipyridine) was synthesized by the addition of $\left[\mathrm{Ru}(\mathrm{bpy})_{3}\right] \mathrm{Cl}_{2}$ (Sigma Aldrich Co.) to an aqueous solution containing the equivalent quantity of $\mathrm{Ag}_{2} \mathrm{SO}_{4}(99.5 \%$, Wako Pure Chemicals Co.). The water oxidation reaction was conducted in a Pyrex topped irradiation-type reaction vessel connected to a glass-enclosed gas circulation system. $50 \mathrm{mg}$ of g- $\mathrm{C}_{3} \mathrm{~N}_{4}$ or $3.0 \mathrm{wt} \% \mathrm{CoAl}_{2} \mathrm{O}_{4}-\mathrm{loaded}$ $\mathrm{g}-\mathrm{C}_{3} \mathrm{~N}_{4}$ was dispersed in a phosphate buffer solution $(100 \mathrm{~mL}, 50 \mathrm{mM}, \mathrm{pH} 7.5)$ containing $\mathrm{Na}_{2} \mathrm{~S}_{2} \mathrm{O}_{8}$ $(97.0 \%$, Wako Pure Chemicals Co., $50 \mathrm{mM})$ and $\left[\mathrm{Ru}(\mathrm{bpy})_{3}\right] \mathrm{SO}_{4}(0.25 \mathrm{mM})$. The solution was irradiated by a $300 \mathrm{~W}$ xenon lamp (Cermax, PE300BF) fitted with cutoff (R-54) and neutral density (ND-10) filters, and a CM-1 mirror $\left(28.1 \mathrm{~mW} \mathrm{~cm}^{-2}\right.$ at $\left.520<\lambda<600 \mathrm{~nm}\right)$ under a degassed atmosphere. The evolved $\mathrm{O}_{2}$ was analyzed using gas chromatography (GC 3200, GL science).

\section{Discussion on Potential Impact of Vacancies in Cocatalysts}

Recently, important roles of oxygen (as well as cobalt) vacancies in $\mathrm{Co}_{3} \mathrm{O}_{4}$ for electrochemical water oxidation have been reported. ${ }^{9-10}$ According to these reports, it has been claimed that introduction of vacancies into $\mathrm{Co}_{3} \mathrm{O}_{4}$ increased the density of active sites and reduces the charge transfer resistance, thereby contributing to an improved OER performance. In our experiments, the photochemical OER activities were almost similar to each other (Figure 13C), indicating similar levels of efficiencies for OER on the material surface, even though the density of vacancies in the loaded $\mathrm{CoAl}_{2} \mathrm{O}_{4}$ and $\mathrm{Co}_{3} \mathrm{O}_{4}$ cocatalysts may be different. Therefore, it is considered that the impact of vacancies existing in cocatalysts is, if any, too small to alter the OER rate that occurs on the surface of the cocatalyst. 

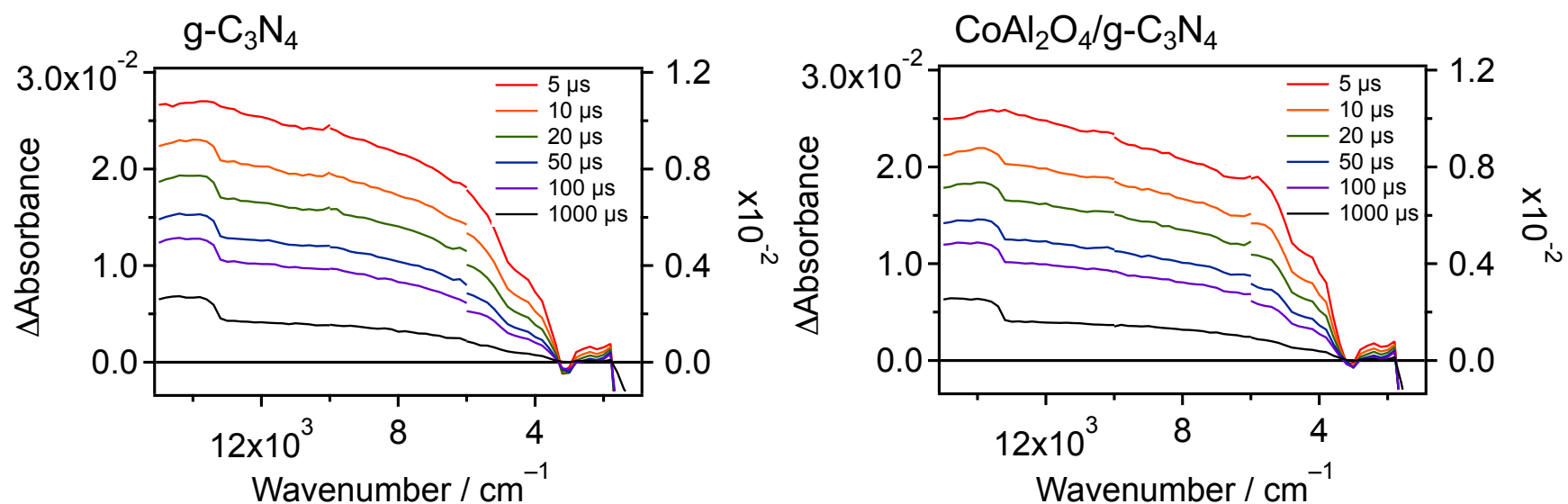

Figure S14. Transient absorption spectra for bare and $3.0 \mathrm{wt} \% \mathrm{CoAl}_{2} \mathrm{O}_{4} / \mathrm{g}-\mathrm{C}_{3} \mathrm{~N}_{4}$ for laser pulse excitation at $420 \mathrm{~nm}$ under vacuum.

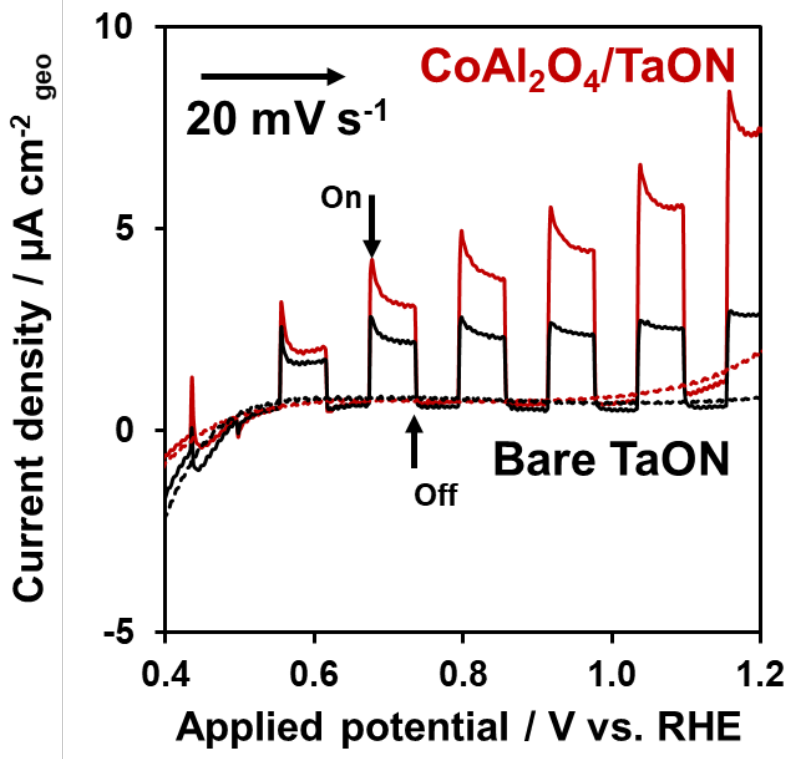

Figure S15. Current-voltage curves for bare or $\mathrm{CoAl}_{2} \mathrm{O}_{4} / \mathrm{TaON} / \mathrm{FTO}$ electrodes in phosphate buffered solution under visible light irradiation. Scan rate: $20 \mathrm{mV} \mathrm{s}^{-1}$.

\section{Experimental Details for Photoelectrochemical Measurement}

Electrodes were prepared by a squeegee method. A mixture of $25 \mathrm{mg}$ of as-prepared $\mathrm{CoAl}_{2} \mathrm{O}_{4} / \mathrm{TaON}$ (or TaON) powder, $5 \mu \mathrm{L}$ of acetylacetone (Kanto Chemicals), $5 \mu \mathrm{L}$ of TritonX (Aldrich), $5 \mu \mathrm{L}$ of poly(ethylene glycol) 300 (Kanto Chemicals) and $125 \mu \mathrm{L}$ of distilled water was mixed to prepare a viscous slurry. The slurry was then pasted onto a fluorine-doped tin oxide conductive glass support (FTO; Asahi Glass, Japan) to prepare a $1.5 \times 3.5 \mathrm{~cm}^{2}$ electrode, and the sample was annealed in a nitrogen gas flow at $673 \mathrm{~K}$ for $1 \mathrm{~h}$. It proved difficult to prepare a high-quality $\mathrm{g}-\mathrm{C}_{3} \mathrm{~N}_{4}$ film, therefore, TaON was used as an alternative semiconductor material.

Photoelectrochemical measurements were conducted at room temperature in $100 \mathrm{mM}$ aqueous phosphate buffer solution ( $\mathrm{pH}$ 7.5) under an argon atmosphere using a Pyrex electrochemical cell with a $\mathrm{Ag} / \mathrm{AgCl}$ reference electrode (saturated $\mathrm{KCl}$ ), a Pt wire counter electrode and the $\mathrm{CoAl}_{2} \mathrm{O}_{4} / \mathrm{TaON} / \mathrm{FTO}$ as the working electrode under potentiostatic control (HSV-110, Hokuto Denoko). The light source was a $300 \mathrm{~W}$ xenon lamp (Cermax, PE300BF) equipped with a cold mirror (CM1) and a cutoff filter (L42). 
Table S1. Photocatalytic activities of various semiconductors modified with $\mathrm{CoAl}_{2} \mathrm{O}_{4}$ for water oxidation under visible light irradiation ${ }^{a}$

\begin{tabular}{lllll}
\hline Entry & Semiconductor & Loading amount of $\mathrm{CoAl}_{2} \mathrm{O}_{4} / \mathrm{wt} \%$ & \multicolumn{2}{c}{ Gas evolution rate $/ \mu \mathrm{mol} \mathrm{h}^{-1}$} \\
\cline { 4 - 5 } & & 2.0 & $\mathrm{O}_{2}$ & $\mathrm{~N}_{2}$ \\
\hline $1^{b}$ & $\mathrm{LaTiO}_{2} \mathrm{~N}$ & 0 & 77.2 & 0.5 \\
2 & $\mathrm{LaTiO}_{2} \mathrm{~N}$ & 2.0 & 48.6 & 0.2 \\
$3^{b}$ & $\mathrm{TaON}$ & 0 & 67.8 & $<0.1$ \\
4 & $\mathrm{TaON}$ & 2.0 & 35.4 & 0.9 \\
$5^{b, c}$ & $\mathrm{TiO}_{2}: \mathrm{Ta}, \mathrm{N}$ & 0 & 15.4 & $<0.1$ \\
$6^{c}$ & $\mathrm{TiO}_{2}:$ Ta,N & 0 & 10.3 & $<0.1$ \\
\hline
\end{tabular}

${ }^{a}$ Reaction conditions: catalyst, $50 \mathrm{mg} ; \mathrm{La}_{2} \mathrm{O}_{3}, 200 \mathrm{mg}$; reactant solution, aqueous $\mathrm{AgNO}_{3}(10 \mathrm{mM}, 140$ $\mathrm{mL}$ ); light source, $300 \mathrm{~W}$ xenon lamp with a cutoff filter (L42). ${ }^{b}$ Annealing temperature: $573 \mathrm{~K} .{ }^{c}$ without $\mathrm{La}_{2} \mathrm{O}_{3}$. Note that the results reported were obtained without optimizing the photocatalyst system or reaction conditions, and that each loading and reaction condition might not be optimal because the surface areas of these photocatalysts differed and, in general, the optimal reaction conditions for a certain photocatalyst are dependent on the type of loaded cocatalyst. ${ }^{111-12}$ Gas evolution rates shown are based on the average values for $2 \mathrm{~h}$ of reaction. 


\section{Supporting Information (SI)}

\section{References}

1. Maeda, K.; Wang, X.; Nishihara, Y.; Lu, D.; Antonietti, M.; Domen, K. Photocatalytic Activities of Graphitic Carbon Nitride Powder for Water Reduction and Oxidation under Visible Light. J. Phys. Chem. C 2009, 113, 4940-4947.

2. Kasahara, A.; Nukumizu, K.; Hitoki, G.; Takata, T.; Kondo, J. N.; Hara, M.; Kobayashi, H.; Domen, K. Photoreactions on $\mathrm{LaTiO}_{2} \mathrm{~N}$ under Visible Light Irradiation. J. Phys. Chem. A 2002, 106, 6750-6753.

3. Hitoki, G.; Takata, T.; Kondo, J. N.; Hara, M.; Kobayashi, H.; Domen, K. An Oxynitride, TaON, as an Efficient Water Oxidation Photocatalyst under Visible Light Irradiation $(\lambda \leq 500 \mathrm{~nm})$. Chem. Commun. 2002, 1698-1699.

4. $\quad$ Nakada, A.; Nishioka, S.; Vequizo, J. J. M.; Muraoka, K.; Kanazawa, T.; Yamakata, A.; Nozawa, S.; Kumagai, H.; Adachi, S.-i.; Ishitani, O.; Maeda, K. Solar-Driven Z-Scheme Water Splitting Using Tantalum/Nitrogen Co-Doped Rutile Titania Nanorod as an Oxygen Evolution Photocatalyst. J. Mater. Chem. A 2017, 5, 11710-11719.

5. Zhang, G.; Zang, S.; Wang, X. Layered $\mathrm{Co}(\mathrm{OH})_{2}$ Deposited Polymeric Carbon Nitrides for Photocatalytic Water Oxidation. ACS Catal. 2015, 5, 941-947.

6. Ravel, B.; Newville, M. Athena, Artemis, Hephaestus: Data Analysis for X-Ray Absorption Spectroscopy Using IFEFFIT. J. Synchrotron Radiat. 2005, 12, 537-541.

7. Yamakata, A.; Ishibashi, T.-a.; Onishi, H. Water- and Oxygen-Induced Decay Kinetics of Photogenerated Electrons in $\mathrm{TiO}_{2}$ and $\mathrm{Pt} / \mathrm{TiO}_{2}$ : A Time-Resolved Infrared Absorption Study. J. Phys. Chem. B 2001, 105, 7258-7262.

8. Hong, D.; Yamada, Y.; Nagatomi, T.; Takai, Y.; Fukuzumi, S. Catalysis of Nickel Ferrite for Photocatalytic Water Oxidation Using $\left[\mathrm{Ru}(\text { bpy })_{3}\right]^{2+}$ and $\mathrm{S}_{2} \mathrm{O}_{8}{ }^{2-}$. J. Am. Chem. Soc. 2012, 134, 1957219575.

9. $\quad$ Wei, R.; Fang, M.; Dong, G.; Lan, C.; Shu, L.; Zhang, H.; Bu, X.; Ho, J. C. High-Index Faceted Porous $\mathrm{Co}_{3} \mathrm{O}_{4}$ Nanosheets with Oxygen Vacancies for Highly Efficient Water Oxidation. ACS Appl. Mater. Interfaces 2018, 10, 7079-7086.

10. Zhang, R.; Zhang, Y.-C.; Pan, L.; Shen, G.-Q.; Mahmood, N.; Ma, Y.-H.; Shi, Y.; Jia, W.; Wang, L.; Zhang, X.; Xu, W.; Zou, J.-J. Engineering Cobalt Defects in Cobalt Oxide for Highly Efficient Electrocatalytic Oxygen Evolution. ACS Catal. 2018, 8, 3803-3811.

11. Zhang, F.; Yamakata, A.; Maeda, K.; Moriya, Y.; Takata, T.; Kubota, J.; Teshima, K.; Oishi, S.; Domen, K. Cobalt-Modified Porous Single-Crystalline $\mathrm{LaTiO}_{2} \mathrm{~N}$ for Highly Efficient Water Oxidation under Visible Light. J. Am. Chem. Soc. 2012, 134, 8348-8351.

12. Wang, D.; Li, R.; Zhu, J.; Shi, J.; Han, J.; Zong, X.; Li, C. Photocatalytic Water Oxidation on $\mathrm{BiVO}_{4}$ with the Electrocatalyst as an Oxidation Cocatalyst: Essential Relations between Electrocatalyst and Photocatalyst. J. Phys. Chem. C 2012, 116, 5082-5089. 